\title{
The Role of International Law and Observance of Its Regulations on Countries Economic Development
}

\author{
Bahman Akbari ${ }^{1}$ \\ ${ }^{1}$ Rasht, Iran \\ Correspondence: Bahman Akbari, Rasht, Iran. E-mail: bahman.akbari1@yahoo.com
}

Received: March 25, 2016

Accepted: June 11, 2016 Online Published: August 30, 2016

doi:10.5539/jpl.v9n7p85

URL: http://dx.doi.org/10.5539/jpl.v9n7p85

\begin{abstract}
The significance of poverty consequences in contemporary social system and the role of economic development in consolidating the basis of international peace and security led to conduct a research on factors affecting the establishment of development. The question - on the one hand-is that: what's the role of International law in economic development and -on the other hand- what's the relationship between observance of regulations of international law by governments and their economic development? Based on the theory of the formation of international law mechanisms derived from it must reflect Humanity's collective demands and in concrete manifestation must found norms that ensure and deepen human rights in the International scope. However, since the governments are considered the first and the most important subject of international law, the achievements obtained by international law cannot be apart from the governments actions, so that national sovereignties normativism and observance of regulations of international law- in line with multiple characteristics necessary for achieving economic development- are pivotal factors in the economic development.
\end{abstract}

Keywords: economic development, international law regulations, national sovereignties

\section{Introduction}

Acknowledging the reality of poverty across the world and the broader range of deprivation and lack of development in some countries gave rise to review its reasons from international law perspective. Extensive regional and global consequences resulting from the lack of development is of the most important international challenges to achieve goals such as freedom, peace and international security. Poverty and its consequences have been the main reason -if it is not the only one - for dissatisfaction of societies in the history. From the hungry peasants revolt which led to the great French revolution - in 1789 - to the self-immolation of young Tunisian salesman who sparked liberal movements in Arabic countries in 2010, the traces of poverty and deprivation is obvious. Also from the individual aspect, since human enjoyment of appropriate living amenities as explicitly stated in the international documents, (Note 1) considered of the fundamental rights and requisite of his growth and development, the continuation of deprivation of people from the aforesaid amenities in a century in which human has sufficiently achieved methods to exploit natural resources and knowledge of the production, it is the fundamental concern in the context of the activities and studies in international law.

There are plenty of resources in relation to economic international law. However, in spite of interpretations and comprehensive explanation of contracts and regulation governing the economic ties, and proposing subjects related to development including variety of variables such as economic, social, political and etc., the importance of following international law and necessity of acknowledging the superiority of international law by national sovereignties as an independent and effective variable in economic development has not been addressed. The other point is that the approach of developed countries is considered as the main reason of poverty in third world countries and the causes of poverty regarding the actions of sovereignties of developing countries have been ignored.

This study believes in independence of the principle of observing international law regulations as an effective variable in economic development and therefore, looks for the main reason of lack of development in developing countries governments behavior.

It is remarkable to note that two variables, i.e. observing commitments and economic development, which are the pivotal subject of the article, have been mentioned in the introduction of Charter of the United Nations (Note 
2)which indicates the significance of them, but it seems the connection between these two is neglected.

The question is this: What role does international law play in economic development and - the other one -what kind of association does exist between observance of international law regulations by governments and their economic development? In other words, in what extent the criteria of norm orientation of governments in the international relations is effective in attaining resources and ways of development? In the discussion on the rules of international law, the main focus is always on observing international commitments that ensure and entail the "Pacta Sunt Servanda" and it can be claimed that the formation and the foundation of international relations are based on it. Nevertheless, the focus of this study is not merely the contractual commitments set out in special agreements or organizational charters and the consequences of violating them by parties, because this is evident and there is no need to prove it. Rather, observing the international obligations, as mentioned in this article, is a transfer to a normative sovereignty and desired governance .The point of focusing also is on the extent of a nation's adherence to the norms that apparently is not related to the structure of the international economy. Another point that, in the discussion of sanctions and their approach to economic development, the only attention is toward international economic organizations affiliated with the United Nations (as the most important organization in the structure of contemporary international law)however, in the case studies we have cited some statistics of other organizations (Organizations unrelated to the UN)in order to prove our hypothesis.

The author believes that considering the principles and regulation governing the economic organizations affiliated with United Nations and by virtue of consensus of almost all of world states as per principles provided in united nations charter, and with reference to the agreement philosophy arising out of the social correlation of nations, complying with international obligations and respect for the rules deducted from international law manifestations, and for fundamental principles such as "Pacta Sunt Servanda" by the national sovereignties are of main components of economic development in countries.

In order to a better coverage the article, we will look at two main parts. In the first part, the role of International law and in the second part the effect of observance of international law regulations (international commitments) in achieving development will be described.

\section{Mechanisms and Capabilities of International Law in the Realization of Economic Development}

\subsection{Mechanisms of International Law in the Realization of Development}

International law mechanisms for implementation, expansion and deepening of the development of societies and, in particular, economic development can be studied from two dimensions. The first dimension is intrinsic mechanisms of international law that can be measured in the context of philosophical analysis and the second is related to the mechanisms embodied in concrete forms (the formal Sources) of international law. Each of these aspects will be investigated further.

\subsubsection{Substantive Mechanisms of International Law}

Since the origins of the formation of contemporary organizations of international law arose out of liberal thinking, and human defined in this school is rights-oriented and the government is not the master but his servant and in charge of his affaires; the first mission of this science in the contemporary system should also reflect human fundamental rights. Regardless of confirming the "Natural Law theory" that according it "the concept of law has its origin in natural notions..." (Piranio, 2015, p.5) or the "Legal Positivism" that it "was a short step to reinterpreting international law not in terms of concepts derived from reason but rather in terms of what actually happened between the competing states" (Show, 2003, p.25) the studies on changes in the field of international law foundations indicate this fundamental and elegant issue that the formed structure of legal rules enjoys mechanisms to identify, follow up and ensure human needs whose legitimacy has already been taken for granted as an achieved phenomenon."Mac Dugal" believes the ultimate goal of international law is to protect human freedom and fundamental rights and as "Immanuel Kant" defines law as recognition of natural rights. "Unilateral intervention by states to secure humanitarian objectives is clearly supported by Teson's view of Kant's work."(Capps, 2001, p. 1020)Abovementioned definitions are in fact a direct reference to the most basic function of law, since the formation of the United Nations -as the symbol of the greatest unity of human history -was based on the idea of "Liberalism", the primary mission of institutions and their established norms in this organization must reflect a fundamental demands of human in order to attain the ultimate goal, so in this respect the first function of the international law can be called "demanding role". When we are discussing about subjects of international law "States" are deemed as the main subject of international law and the people known as the last, but it should not give rise to a doubt that there is no place for people in this area and they are in the least level of importance, rather, in the current social-political system, international law governing relations between states and international organizations in order that, ultimately, the rights of "persons" to be followed and 
processed from the international aspects; According to the first paragraph of Art. 2 the Declaration on the Right to Development (1986): "The human person is the central subject of development and should be the active participant and beneficiary of the right to development."(Note 3) "The developing concern with human rights is another aspect of this move towards increasing the role of the individual in international law." (Show, ibid., p.45) So in the area of international economic discussions at first the elimination of poverty, removal of the class gap and strengthening economic security of communities should be called for and get the national governments to pay attention to the message that poverty is an unfortunate reality which has always been dangerous to mankind and their world, and poverty in the south of the world affects the peace of the north. "Jean-Jacques Rousseau" in "social contract" writes: "a large measure of equality in rank and fortune, without which equality of rights and authority cannot long subsist; ..., we should understand, not that the degrees of power and riches are to be absolutely identical for everybody; ... in respect of riches, no citizen shall ever be wealthy enough to buy another, and none poor enough to be forced to sell himself."(Rousseau, 2002, p.52,39)

Meanwhile, no other mechanism is not as able as international law (with its whole structural) is to adopt appropriate approaches to reflect this "Nearly 870 million people, or one in eight, were suffering from chronic undernourishment in 2010-2012, according to the new UN hunger report released today... more than 100 million children under five are underweight." (Food and Agriculture Organization[FAO], 2012)-“There are 66 million primary school-age children who attend classes hungry across the developing world...” (World Food Programme[WFP],2012) In such a situation, the first role of international law is to reflect the existing realities, explaining the consequences of the continuation of current situation and also demanding the fundamental rights of individual and reminding this important point that the mentioned circumstances are among factors of emergence of many regional and international crises. Outbreak of radicalism thoughts, terrorism, drug production and trafficking, insurgency, riots and civil wars with broad regional and global consequences and refugee crisis and dozens of other tragedies are caused by multiple factors such as poverty, deprivation and class gap, which themselves are added to the effect of the poverty and declining living standards of community. It is not difficult for governments to understand the fact that the fulfillment of the needs and observance of citizens' rights, which are the real owners of wealth and land resources, are far less costly and more rational. Therefore, the organizational structure and doctrinal instruments of international law must remind the governments that according to aforementioned article and other anticipated regulations, achieving the economic welfare is of their primary and obvious tasks and, on the other hand, the economic international law must lead the human communities to promote living standards at the end of its actions and any orientation out of this purpose means outshining the main goal.

To create and explain norms appropriate for realization and ensure the human demands and in the other words "normalization role" is the other substantive mechanism of international law. "International law... is primarily formulated by international agreements, which create rules binding up on the signatories, and customary rules, which are basically state practices recognised by the community at large as laying down patterns of conduct that have to be complied with."(show, ibid., p.6 )Meanwhile, governments obedience of said norms is a requirement for the fulfillment of goals on which international law has been based. Thus, as "Hans Kelsen" believes: "International law can no longer perform it's essential function of Coordinating, of equally ordering, all states."(Kelsen, 2002,p.117 )"There are other factors inherent in the very nature of international law and of international society which induce states to obey international law...It is not difficult to see why it is in the interests of states to agree to rules of international law. States are naturally interdependent in many ways (for example, international trade ), and international law facilitates international co-operation, states have a common interest in preventing pollution of the sea ... and a treaty or some other legal instrument is the obvious way of laying down the necessary rules."(Akehurst, 1987, p. 8 )

\subsubsection{Formal Mechanisms of International Law}

The next point of focus on the mechanisms of international law is the significance of formal sources of international law in development. The role of "international treaties" such as stressing the need for economic growth and development by approving documents such as "International Covenant on Economic, Social and Cultural", "general principles" which respect for it guarantees stability and security of contracts and nations relations in the international level, including trade and international economics, "the decisions of international organizations" such as development-oriented approaches adopted by institutions such as the "United Nations Conference on Trade and Development" etc. all represent potential capabilities of mechanisms of this area is in the format of formal sources of international law.

It is worth noting that in the area of international economic development the most important, effective and objective mechanism of international law have always been international organizations approaches. The 
formation of international economic institutions with the ultimate goal of improving the living standards indicates creating institutionalist-oriented opportunities to offer different approaches by different groups in international area (sometimes regardless of the scope of totalitarian and nationalist political tendencies, sometimes least affected by these tendencies and sometimes with a balance in political interactions)whose more or less impact on the realization of the common needs and goals of the international community is undeniable. "The proliferation and differentiation of IOs, and the expanded range and significance of their activities have been understood as a challenge (and opportunity) for international law since the 1860 s or earlier." (Kingsbury \& Casini,2009,p.326-327) In the meanwhile,institutional thinking plays an important role in analyzing the reasons of socio - economic failure of international community in the period of political life leading up to World War II, outlining the prospects for economic development of communities through economic interdependence and integrating diverse civilizations and nations thoughts in order to overcome the challenges ahead.

Another point that worth mentioning is that although the said resources have been known in line with each other, on top of all "jus cogens" is the most important, the most basic and the most fundamental point of these sources. "...the concept of jus cogens, of fundamental and entrenched rules of international law, is well established in doctrine now, but controversial as to content and method of creation."(show, ibid., p.850 )Different views on the "jus cogens" are that some scholars deem it independent sources and some know it as part of general principles. Apart from the belief in the unity of the examples of "jus cogens" with general principles or segregation from each other, a review on the instances and acknowledging governing and the presence of traces of "jus cogens" not only in general principles but also in convention, treaties and procedure, it is clear that the mentioned principles are among the most primitive and evident norms governing international interactions and its examples are of fundamental necessities for international relations, and respect, commitment for and observance of it is considered as a necessity to attain justice and international stability. Among these rules the principle of "pacta sunt servanda" can be mentioned. This principle explains the importance of respecting international commitments which its relationship with the economic development is the core discussions of this part and will be explained in further chapters.

According to what have been discussed about the substantive mechanisms of international law and its objective representatives capabilities in putting forward and consolidation of individuals demands, the place of the international law in the creation of commitment deducted from international consensus on issues such as unity and security of nations through economic channels; and on the basis of the norms created based on the common interests of communities seems important. Mechanisms that in the international economic scope must be aimed at only one thing: economic development of communities and promoting human life.

\subsection{Major Capacity of International Organizations in the Realization of Development}

"At the time of the conception of the new UN system after the Second World War it was felt that the world needed more international governance in order to avoid repetition of what had lead to the war that had just ended. Since then the world has become increasingly complex, with ever increasing need for international governance."(Oden, 2010, p. 274) The success of the United Nations in this regard was that to create solutions for identifying, following and realizing economic development as integrating different theories have accepted two fundamentally different school of thought in the scope of international relations in itself, each of which reflects the needs and strategies of economic development sometimes the same and sometimes different from each other. On the one hand, the organizations based on "Bretton Woods" system such as World Trade Organization (WTO) representing orthodox and liberal thinking to global economy, and on the other hand the organizations emerged in the context of "General Assembly" approaches such as United Nations Conference on Trade and Development (UNCTAD) and other privileges received by "the Group of 77" (G 77) that reflect the thoughts and needs of "Critics" to the development. Therefore, the capabilities of international organizations as the criteria for assessment of apart of capacities in the development of international law will be discussed under the two following titles:

\subsubsection{Bretton Woods: World Meeting for Amending the Future of Economy}

“...free trading countries should follow their current comparative advantages in their importing and exporting decisions, regardless of their stage of economic development (dynamic).The basic rules of the General Agreement on Tariffs and Trade (GATT) follow this static principle.”(Miller, 2008, p.117 ) Therefore, "Bretton Woods" must be considered as the continuation of approaches to freedom of trade and competitive advantage adopted by "Adam Smith" and "David Ricardo", which was formed, due to erroneous consequences resulted from nationalistic policy of some states in second World War to be as a vehicle for solving global economic challenges. One of the most important goal is to establish a balance between the interests of governments and 
economic stability in the international scope proposed by "John Maynard Keynes". "Bretton Woods" possessed three elements. The first one is economic growth which its responsibility was assigned to the "International Bank for Reconstruction and Development". The second element, monetary stability which its realization was followed within the International Monetary Fund (IMF) and the third element, is free trade -outlook that the "most favoured nation treatment", reducing tariffs and economy without government intervention formed its essential components- that gave rise to signing GATT. But since its foundation the place of GATT has always been temporary and its qualification has been restricted and has been considered as a framework of international trade after the Second World War and as an alternative for International Trade Organization (ITO) and in fact "GAT was to be an interim arrangement pending the conclusion of the Havana charter (ITO), Which was to incorporate GAT."(Shukla, 2000, p. 2)The final document "Uruguay Round" was signed in April 1994 in Morocco by the representatives of 111 countries and it was agreed to establish WTO by 1 January 1995. This organization which was part of the GATT in the past spread its qualifications, approaches and programs area largely by setting and applying several agreements. The organization always tries to balance the interests of national governments and free market economy by determining the scope of duties and powers of them.

Undoubtedly, to extend the formation of these organizations is a joined and related string derived from liberal thought that appreciates the role of international organizations to the success of societies in unifying nations and achieving international stability and has always been hopeful to realize their aspirations in the face of criticism and doubts emanating from "Realism" thinking. It is not necessary, at this moment in time, to substantiate or reject the need for activism of the "K group" and "hegemony" of the realists and institutionalists as the elements of the formation of organizations arising from the "Bretton Woods", because the influential factors in the mentioned process are supporters of the idea that emphasizes the role of trade and subsequently "interdependence" resulted from "free economy" in order to reduce conflicts among governments. Also "this regime, guaranteed by the Bretton Woods system, maintained a balance between openness, democracy, and economic fairness." (Trubek, 2003,p. 9) The author believes that if we count multiple reasons for failure to attain inclusive economic development and even consider it as a result of existing gaps in the approaches of discussed institutions, but the nature of establishing and the philosophy of formation of these organizations indicates the concern of economic development and the expansion of human welfare.

\subsubsection{General Assembly: The Opportunity for Critics to Represent the Development Strategies}

From the liberal perspective, the main factor of poverty in the world is nothing but governments intervention in economic activities and their protectionist policies. (Note 4) Thus, to limit the role of governments in to the "welfare state", lowering tariffs, leading market naturally through demand and supply channels and in short: a free market economy in the framework of WTO is the factor of economic development in countries. In the contrast, critical approach knows these policies as a cause of reinforcing big companies, major shareholders, industrialized countries and underlying more class gap and less development. Also, critical thinking believes that the main cause of underdevelopment in the Third World is development of industrialized countries as a result of the colonial policies of these countries. Therefore, in line with economic approaches of affiliated organizations of the "United Nations" governing system of the "General Assembly" (One state - One vote) provided an opportunity for developing countries to follow their positions in order to account for their interests in the form of statutory approvals backed by the multiplicity of their votes. Along the $1960 \mathrm{~s}$ three organizations were established aimed at economic development in developing countries: the "United Nations Conference on Trade and Development", (Note 5) "United Nations Development Program" (UNDP) (Note 6) and "United Nations Industrial Development Organization"( UNIDO). (Note 7)In fact, these three organizations should be known as the Development-oriented triangle of south of the world. The organizations that by their efforts in the context of General Assembly's activities we have witnessed legislations such as the "Declaration on the Right to Development", the creation of concepts such as "the common heritage of mankind" and lay strategies such as "United Nations Development Decades".

According to all issues reviewed in this chapter briefly, it must be acknowledged that the nature of existence of the United Nations organizations and institutions such as "General Assembly" and actions arising from the context of its legislation in the last half century has been able to create effective mechanisms and approaches in the development of the international economy along with considering the needs of developing countries. Stipulating the principle of "equality of nations" in the UN Charter was promising, in advance, to create a space that in the middle of economic competition and profiteering recorded in the memory of history majority of votes of countries of the south in parallel with the international consensus arising from the formation of United Nations it could make an opportunity for these countries to provide their views and carrying forward theme. Although the adopted approaches in mentioned decades and the performance of institutions such as UNCTAD were not able to 
achieve their goals completely, existing factors and obstacles cannot be related to the nature of the United Nations and its legal thinking basis, as the reasons for lack of development and the causes of poverty and economic deprivation seem to be numerous, unknown and may be out of sights. The next part of this article is an analysis of the one of the most basic reasons of lack of economic development.

\section{The Effect of Observance of International Law Regulations and the Consequences of Non-Compliance with Law on the Economic Development}

Despite the differences in definitions and numerous indicators to measure economic development and the existence of multiple causes and solutions for development, the effect of some economic factors as negative and positive factors affecting the development or lack of economic development is obvious. Undoubtedly, no common sense ,per se, disclaim the role of foreign investment in strengthening the national economic, as it's no secret the harmful consequences of violence and punishment approaches adopted by international organizations toward a country. But what constitutes the basis of this study is the relationship between compliance with international commitments and to attain affecting economic development components and its negative aspects in case of lack of complying with commitments.

Legal principles as well as the principles governing other relationships and institutions monitoring human civilization are among the basic foundations governing the system of international law. The principle of compliance with the commitments in the international law is the continuation and expansion of "pacta sun servanda" in the domestic legal systems and imagination of a society that its members do not adhere to the agreements concluded by themselves is so frightful and its result seem to be catastrophic. As "in determining the effect of treaties, the adage pacta sunt servanda (agreements are to be kept) remains a foundation of international law."(Park \& Yanos, 2006, p. 1)So in the scope of nations relations with each other "international treaties" and consequently compliance with the commitments derived from it must be known as the most important mechanism to create solidarity among nations, realize their common interests and maintain their collective security. "The international law believes that nothing can be done without or against the will of a sovereign State International Treaty law is therefore a meeting point of the necessity to take international obligations (some kind of limitation on exercise of sovereignty and protection of sovereignty)"(Sangroula, 2010,p. 2)

In the introduction of "the Vienna Convention on the Law of Treaties 1969" (VCLT) (Note 8) says "Noting that the principles of free consent and of good faith and the pacta sunt servanda rule are universally recognized". As it can be seen, the "legally binding of international commitments" has been regarded as a principle of legal rules which comes with the principle of "free consent" and "good faith", the former ,in fact, voids every excuse to violate the rule of legally binding of commitments. Art. 26 says about the Treaty's binding: "Every treaty in force is binding upon the parties to it and must be performed by them in good faith". And immediately the Art. 27 says: "A party may not invoke the provisions of its internal law as justification for its failure to perform a treaty." So on the basis of this Article, by the adoption of an international treaty a government limits a part of its local authority area to the rules of international law. Art. 43, in order to stress the significance of commitments under international law independent of the treaty itself, acknowledges: "The invalidity, termination or denunciation of a treaty, the withdrawal of a party from it, or the suspension of its operation, as a result of the application of the present Convention or of the provisions of the treaty, shall not in any way impair the duty of any State to fulfil any obligation embodied in the treaty to which it would be subject under international law independently of the treaty." The article, in fact, suggests the importance of international commitments. It should be noted that according to Art. 63 of the Convention, cutting diplomatic or consular relations is not an acceptable reason for non-compliance with international commitments.It says: "The severance of diplomatic or consular relations between parties to a treaty does not affect the legal relations established between them by the treaty except in so far as the existence of diplomatic or consular relations is indispensable for the application of the treaty." Therefore, acknowledging the importance of the principle of compliance with the international commitments as one of the fundamental principles and a clear example of "jus cogens" of international law, according to this paper adherence to the discussed principle by national sovereignties guarantees fundamental goals of Charter and other documents of the "United Nations" including the realization of economic development. The season that deals with explanation and proving the said hypothesis will be followed in two parts. The first part is the explanation of achievements of compliance with international commitments and its case studies and in the second part the economic consequences of violating international commitments will be adrressed.

\subsection{The Economic Achievements of Compliance with International Commitments}

\subsubsection{Create Components Needed for Entering into the World Trade}

Today, after more than half a century since concluding the GATT agreement and during two decades of 
role-playing of WTO despite the different views, the requisiteness of participating in world trade and its effect on growth and economic development is undeniable. "The comparison of empirical economic data, more than ideological factors, between countries with growth (mainly in Asia) and stagnant regions pointed to economic liberalization and domestic reforms as the main driving forces of growth."(Dolzer\& Schreuer, 2008, p.79) The necessity of entering to this field is due to interdependency and the countries mutual needs in a world whose memory is full of strife and conflict over national, racial, partisan and even personal benefits! The positive approach toward the nature of the WTO, as it was discussed, is mostly because of philosophy of the formation of the "Bretton Woods" which one of its most important aims was to "balance the interests of governments and economic stability".

Joining to WTO entails a long process and in virtue of a continuous negotiations "not all the Member countries of the WTO are democracies..."(Howse, 2000, p. 7)but the organization should be ensured that requesting party adjust its domestic laws with the regulations of agreements and meet the required expectations. Moreover, "encouraging desirable sovereignty" is of the organization's aim to which four elements are related: "Transparency - shared information and knowledge - levels the playing field. Rules reduce arbitrariness and opportunities for corruption. They also shield governments from lobbying by narrow interests." (Note 9)

It should be noted that the WTO is based on political neutrality. Therefore, the principles governing the organization should not be political in nature, while it is reasonable to admit that prerequisite of trade liberalization among member countries is their coordination according to the standards that they have agreed. For example, Member States must publish the rules and their business frameworks and make them available to public. Foreign investment is among the major components of WTO. "There are many research about [The relationship between FDI and] economic growth; Yao's research from 1978 to 2000 in china, shows that FDI has significantly positive effect on economic growth."(Nourbakhshian, Hosseini, HajAghapour \& Gheshmi, 2012, p.279) But the most important factor which make it an influential factor for development is countries economic interdependence in foreign investment process. Nowadays, "Multi-National Corporations", plays a significant role in economic growth. It is worth noting that UNCTAD knows foreign investment necessary for economic growth and eradicating poverty in developing countries. Moving "foreign direct investment" FDI towards developing countries belies the theory that these investments are absolutely aspect of neo-colonialism of nations. In practice, these types of investments are done in countries that meet the required components such as: sales market, free economic environment, conducive domestic law and political stability. Therefore, according to the objectives of the World Trade Organization, the principles of organization's agreements, evident and certain facts and requirements of the business world and foreign investment components such as transparency and internal security, which are deemed as aspects of desirable sovereignty, are regarded as the main criteria of development achievements.

\section{Case Study: Qatar}

Benefiting from revenues from the production and export of oil and gas, this country now is known as the richest country of the world. According to the World Bank statistics, Qatar with 87.478 million dollars per capita income in 2013 owned the highest per capita income in the world. Qatar is a member of "the Organization of the Petroleum Exporting Countries" and the largest holder of gas reserves after Russia and Iran. Before the discovery of oil, pearl hunting and sea trade was the main economic source of the country. Now, oil and gas export is the country's source of currency revenues. Investment and ideal utilization of "South Pars" gas field are some accelerating factors of Qatar economic growth in recent years. South Pars gas field which is called "North Dome gas field" in Qatar is the largest gas field in the world and located in Persian Gulf and Iran's and Qatar's territorial waters. If optimal use of the country's oil and gas reserves regarded as one of the main reasons for Qatar's economic growth and attracting foreign investment deemed as the main reason for the country's progress in the exploitation of its natural resources, one of the most basic elements of attracting foreign investment, surely, is country's economic, social and political stability and security. Among the reasons to substantiate this claim is "global peace index". According to the "Institute for Economics and Peace" report Qatar was placed in 19 and 22 place in the years 2013 and 2014 respectively in peace index. In this respect, it is considered as one of the most peaceful countries in the world. "Qatar has not experienced domestic unrest or violence like that seen in other Near Eastern and North African countries in 2010-11...however Doha has prided itself on its support for many of these popular revolutions, particularly in Libya and Syria." (The World Factbook, 2014) But the other evidence is "Transparency International Organization" report (2013)which according to it Qatar in "Corruption Perception Index" was in 28 place among 177 countries in 2013, which in this respect it is among the countries with the lowest administrative corruption level. Qatar in the Arab world is now at the highest level of "Human Development Index" (HDI) and on an international scale also ranked 31 in the world. The "gross national 
income per capita"(GNI) of Qataris $\$ 87,478,000$ which is ranked 1st in the world. The "life expectancy" or "health" in this country is 78.5 years, the "education index" is 7.3and"gender inequality" is 0.546 . (United Nations Development Programme[UNDP],2013)

\subsubsection{Allocation of International Facilities by World Bank}

According to the section tenth of Art. 4 the World Bank Agreement: "The Bank and its officers shall not interfere in the political affairs of any member; nor shall they be influenced in their decisions by the political character of the member or members concerned. Only economic considerations shall be relevant to their decisions, and these considerations shall be weighed impartially in order to achieve the purposes stated in Art. I." So, the mission of World Bank is achieve to the objectives set forth in Art. 1 based on political neutrality enshrined in Art. 4. But it should not be deducted from the political neutrality of World Bank, as a requirement, that there is no relation between providing facilities and applying financial plans by the institution to development and Member States normalization and lawfulness. It also should not be assumed that any change in the organization approach in return for national and international actions of Member States is against the stipulated standards of the organization. It should be noted that the political neutrality is by no means a license for legal negligence and recklessness; thus, the rule of law in member countries sometimes objectively and in accordance with the articles of agreement of the World Bank and sometimes implicitly is part of basic components contributing to the successful implementation of World Bank projects in order to reconstruction and development. Following reasons to prove this issue are noteworthy:

1) According to Art. 3, Section 5, paragraph b: "The Bank shall make arrangements to ensure that the proceeds of any loan are used only for the purposes for which the loan was granted, with due attention to considerations of economy and efficiency and without regard to political or other non-economic influences or considerations". Therefore, the World Bank allocates loans to projects that result in significant economic benefits for the recipient of the loan.

2) Despite relative independent legal personality of international organizations of it should be considered that not only specialized and affiliated organizations of the United Nations, but also the activities framework of all international organizations follow international law and even continental and regional institutions in case of violating the principles governing international community must be accountable for their actions, as well. While, the World Bank is one of the specialized institutions of the United Nations and, naturally, required to comply with the provisions of the UN Charter and despite the independent legal personality of this institutions, according to Art. 6, paragraph 1 the Agreement concluded between the World Bank and the United Nations the Bank is obliged to adapt its approach toward decisions of the "Security Council" which have been taken pursuant to Art. 41 and 42 .

3) Objectives of each organization, parallel to explaining prospects of interest, involves related principles. In this regard, when in the first paragraph of Art. 1 it is mentioned that reconstruction is one of the aims of WBG, immediately the sentence is mentioned that foreign investment is among the ways of realizing development. As previously mentioned foreign investment requires to create contexts which are provided as the result of norm-oriented and regulated policies by governments. This organization also in explaining two goals: (1) End extreme poverty by decreasing the percentage of people living on less than $\$ 1.25$ a day to no more than 3\% (2) Promote shared prosperity by fostering the income growth of the bottom $40 \%$ for every country." (Note 10 ) Governmental reforms, increasing government accountability and governments role in improving competition, promoting desirable investment environment, encouraging innovation and etc. are considered essential... Therefore, World Bank's approaches and objectives based on stipulated articles and its legal texts are widely in association with the national governments legitimacy.

4) In addition to all abovementioned cases, it should not be ignored that that "when states create an international organization, they set it up for specific purposes and give it limited powers."(Akehurst,ibid, p. 71) As the voting method in IMF is weighted voting system and is done based on members quota. Here may "Realistic" view seem more highlighted and challenge "Liberal" thinking optimism or doubt arise in the nature of these organizations or maybe some others believe in extreme effective and essential role of "hegemony" in these organizations approaches. However, these economic organizations performances- acknowledging the relative process of development and perpetuation of poverty all around the world- indicate the belief of organizations in the need to improve the quality of life of communities and is an evidence of their structural ability in the development of international economics."Over the last several years, the International Finance Corporation's (IFC)"Performance Standards" have become the most widely-accepted framework among international project financiers for managing environmental and social risks of projects in the developing world."(Herz, et al., 2008,p.2)Further, 
welcoming the organization and their resolutions by the international community and development of their universality would oblige Member States to follow the created rules and norms. Norms that bulk of it compared to the past history of the world represents the best international rules (such as the provisions of the Conventions on Human Rights) and have been stimulated the most efforts to stabilize it.

It is worth noting according to the report which presented by the committee of World Bank on the occasion of the fiftieth anniversary of the "Universal Declaration of Human Rights" "This theme is strongly supported by World Bank research, which suggests the strong link between economic performance with accountability and the openness of governance" (The International Bank for Reconstruction and Development \& The World Bank [IBRD \& WB],1998)

\section{Case Study: The Republic of Singapore}

Despite the country's lack of natural resources, but "at the same time Singapore subsequently became one of the world's most prosperous countries with strong international trading links (its port is one of the world's busiest in terms of tonnage handled) and with per capita GDP equal to that of the leading nations of Western Europe." (The World Factbook, ibid) According to the World Bank Statistics "in 2013, the "Gross Domestic Product" (GDP) of the country was 297.9 billion dollars, GDP growth and inflation rate were $3.9 \%$ and $2.4 \%$ respectively."

"Singapore has a highly developed and successful free-market economy. It enjoys a remarkably open and corruption-free environment, stable prices, and a per capita GDP higher than that of most developed countries. The economy depends heavily on exports, particularly in consumer electronics, information technology products, pharmaceuticals, and on a growing financial services sector... Singapore has attracted major investments in pharmaceuticals and medical technology production and will continue efforts to establish Singapore as Southeast Asia's financial and high-tech hub." (The World Factbook, ibid) The country which is composed of many islands now is one of the largest commercial centers in the world and world's tourism hub which enjoying this aspect of the business is moving toward more economic development. According to the "Institute for Economics and Peace" report in 2013 and 2014, the Republic of Singapore ranked 16th and 25th respectively in the world for the "Peace Index" which is among the "very quiet" countries in this respect. "World Bank President Robert Zoellick visited Singapore in December 2008 to sign a Memorandum of Understanding with the government of Singapore, agreeing to establish a World Bank-Singapore Urban Hub in 2009. Leveraging the development expertise of both Singapore and the World Bank, in its first year of operation the Hub will develop collaboration on at least five projects, focused on the thematic areas of city management, city financing, urban design and climate change; deliver workshops and training programs; begin the creation of a virtual knowledge network; and develop and pilot advisory products for urban practitioners ."(World Bank Group[WBG],2010). According to "Transparency International" in 2013, Singapore ranked $5^{\text {th }}$ between 177 countries for the "Corruption Perception Index "which is considered as one of the Very Clean Countries. This country is also in $18^{\text {th }}$ place in the world in terms of "human development index" of the United Nations. Based on the presented indexes in 2013 ,the "Gross national income per capita" " life expectancy", "education index" and "gender inequality rate" were 52.613000 dollars, 81.2,10.1 and 0.101 respectively. (UNDP, ibid)

\subsection{Economic Consequences of Violating International Commitments}

\subsection{1 (Economic) Depression Arising from Isolation and Lack of Political Stability}

Violation or even non-admittance of the general rules of international law by a government causes that the aims and ideology of said government treated inconsistent and contrary to the aims of other governments in international scope and give rise to social discontent and its subsequent results domestically. In other words, two crises will arise around government's political actions a result of applying this approach in the long term: 1 . Political Isolation, 2. Political Instability, which among the consequences of any of crises, alongside many other widespread domestic and regional consequences, is the economic depression and disorder in the process of development.

In terms of political isolation a state moves away from joint economic activities with many other countries or financial institutions affecting the nations' economy which such a situation usually coincides with international economic sanctions. However, looking merely at a situation in which one state is restricted to its domestic land or interacting with a few close regimes (ideologically) due to its rejection from accepted norms and breach of commitments naturally and according to prevailing standards in the context of the international community and its institutions, offering various facilities and building partnerships from the institutions responsible for such a state will stop. For example, as the voting method in IMF is weighted voting system and is done based on members' quota, if a government finds other sovereignty threatening factor, of course, that government's political approach will be effective in its vote. IMF and World Bank adjustment loans are granted to developing 
countries just in case they take the necessary economic reforms. On the other side, propaganda against the government lead to negative perceptions in the minds of international community and overshadows many aspects of government's economic interactions. For example: The cooperation agreements with other effective countries will be reduced, productive resources such as tourism will be stagnated, elites immigration will rise and many other financial and economic consequences.

In the absence of political stability which generally internal and international pressure simultaneously triggers it, another dimensions of stunted economic growth and development occur. Among the most important of which is the failure to attract foreign investment. The functional result of this economic approach after attracting it is directly related to manner of national government. "Productivity and technology spillovers are not automatic consequences of FDI. Instead, FDI and human capital interact in a complex manner, where FDI inflows create a potential for spillovers of knowledge to the local labor force, at the same time as the host country's level of human capital determines how much FDI it can attract and whether local firms are able to absorb the potential spillover benefits."(Blomstron \& Kokko, 2003,p. 4)Thus, despite the existence of resources and tools needed to enjoy the benefits of foreign investment if we only care about the relative effects of these investments, in the absence of political stability, which is of crucial requirements of attracting foreign investment, the economy and development caravan of a community will be left behind of a growing trend resulted from comparative advantage of attracting investment. "Transnational Corporations" have now a significant role in the global economy so that the GDP of large Transnational Corporations are more than many large developing countries. Increased employment rates, economic growth, technology and update knowledge transfer, and much other positive economic effects are the results of these companies' activities in the host countries.In fact "multinational companies (MNCs) have been engines of global economic development, technological transfer and deepening globalization"(Hunya, 2012,p.1) the most basic issues associated to these companies' activities is non-economic risks the so-called "political risks".

Discussion on political risk is directly related to the quality of national sovereignties, Governments norm orientation in the international scope, their compliance with the principles governing the international community and respect for international commitments. In other words, no factor is as effective as democracy and rule of law in creating or shaking political stability. "It is clear from these shortcomings that political risk insurance is a second best policy. A first-best policy involves moving toward investment policy reform and creating sound policy environments in all countries."(Gordon, 2008,p.106 )It is worth noting that UNCTAD knows the political stability of the host country's fundamental components in attracting FDI. The possibility of any of the political risks, "macro" or "micro", reflects the socio-political stability of a country which is an important factor in economic development and improving people's welfare. "Such institutional traits as democracy, a separation of powers (that is, the existence of veto players), rule of law, and bureaucratic efficiency work to decrease transaction costs as well as the risk of harmful government intervention, not least because they mitigate the obsolescing bargain mechanism."(Jakobsen,2011,p.26) In other words, nowadays organizations derived from social arrangements and the responsibilities delegated by the people to their representatives are the very embodiments of human and moral guarantees in the form of legal aspects. Therefore "to achieve positive welfare effects of FDI inflows, governments first have to tackle the institutional setting and regulatory framework in their countries"(Busse \& Groizard, 2006,p.21) and, certainly the fundamental point for social organization and adjustments is better rule of law, respect, adherence to and responsibility towards the commitments made in national and international area. "While in the past political risk was often conceptualised in terms of hostile action by host countries' governments, with the quick pace of globalization its nature and sources have considerably changed, raising the interest of scholars belonging to different fields, from international economics to international relations, from empirical political science to psychology and decision theory. In an era in which global equilibria have changed and once clear-cut distinctions such as "developing" vs. "developed" countries have become blurred, intelligence and risk management have become a major source of concern."(Sottilotta, 2013,p. 13)Such inference from the fact and the nature of political risk indicates on the one hand the multiple layers involved in political risk and the other one is pointing to the depth of adverse effects of the undesirable ruling.

\section{Case Study: Democratic Republic of the Congo}

This country enjoys many natural and mineral resources, so that the value of Congo's mineral resources has been estimated as much as U.S and Europe GDP (24 trillion dollars). The country possesses significant reserves of tin, zinc, gold, uranium, oil and eighty percent of world's Coltan stones. The vast forests in the country placed more than half of sub-Saharan Africa's timber reserves in itself. Congo is the largest producer of cobalt in the world, the largest copper producer in Africa and the second largest diamond producer in the world. Coffee, tea, cocoa, 
caoutchouc and palm products exported from the country. While the country is considered as one of the richest countries in the world in terms of natural resources, its people are among the poorest people in the world. According to the World Bank report in 2013, Congo's GDP was $\$ 30.63$ billion and its growth rate $8.5 \%$. . Also, "based on the estimates accomplished (until 2006), 71\% of the population lives below the poverty threshold." (The World Factbook, ibid)

Socio-political experience of the past few decades in this country prove this claim that among the reasons for the prevailing widespread poverty of the people of Congo are: lack of Socio-political stability, destructive internal conflicts and persistent unrest prevailing in the country. This country was established in 1908 as a Belgian colony until it gained its independence in 1960. From the early years of independence, it run afoul of socio-political instability. Contribution of a large number of African countries and numerous armed groups in the conflict in Congo after1997 have caused this conflicts are mentioned as the "African World War".

A relative peace has been prevailed on the country by the UN forces involvement, but war and unrest, particularly in the east of the country continues. According to the "Institute for Economics and Peace" in 2013 and 2014 DRC ranked 156 and 155 respectively in the "peace index" between 162 countries and is considered, in this respect, as one of the least peaceful countries in the world. During internal conflicts countless innocent victims of malaria, diarrhea, pneumonia and malnutrition have lost their lives. According to The Guardian findings published in the "American Journal of Public Health" in June 2011 about 48 women are raped in the Democratic Republic of the Congo every hour.(The Guardian,2011) The study conducted by three public health researchers of "International Food Policy Research Institute" (IFPRI ) at the Stony Brook University in New York and in partnership with the World Bank and the Government of the United States based on a statistical study of 3436 Congolese women between 15 and 49-year-old in 2007 found that 12 percent of women have been raped at least once in the country and it is worth noting that the crisis is not limited to conflict zones so that it has been extended to the homes of people. In the atmosphere in which the most fundamental rights and the privacy of citizens of a country is easily exposed to violence and aggression, economic poverty and the destruction of resources and opportunities for growth and development is another obvious and indisputable aspect of this situation. Axis of all civil unrests, social insecurity, the neighboring countries interferences, the emergence of opposition groups, armed militias activities and in a word, what can be the root of the lack of socio-political stability of a country other than an undesirable ruling and the absence of the rule of law?

In describing the level of transparency in the government's actions are also notable example "the DRC signed a Poverty Reduction and Growth Facility with the IMF in 2009 and received $\$ 12$ billion in multilateral and bilateral debt relief in 2010, but the IMF at the end of 2012 suspended the last three payments under the loan facility - worth $\$ 240$ million - because of concerns about the lack of transparency in mining contracts." (The World Factbook, ibid) According to the "Transparency International" in 2013 DRC ranked 154 among 177 countries in the "Corruption Perception Index" which in this case has one of the highest ranks of corruption in the world.

This country is also among the worst countries in the world (186) in the "Human Development Index". According to estimates in 2013 the "Gross national income per capita", "life expectancy", "education index" and "gender inequality" were 319,000 \$, 48.7 years, 3.5 and 0.681 respectively.(UNDP, ibid)

\subsubsection{Economic Sanctions}

Economic sanctions have long been used as a political tool of the states in case of conflicting with other powers. The investigation showed the history of effect of sanctions date back to about 2000 years ago. "Thucydides, writing in the fifth century B.C., was perhaps the first to chronicle the impact of sanctions."(Collins, 2009,p. 237) But today, the legitimacy of UN sanctions is based on Chapter VII of the UN Charter. According to international consensus on the objectives and principles of the UN, Security Council is allowed to take determined and effective measures in accordance with Art. 39 against breach of international norms and the establishment of international peace and security. The legal basis for sanctions, in this regard, is Art. 41 of the Charter and the principles requiring countries to comply with Security Council sanctions is Art. 25. Accordingly, it can be said that applying sanctions are resulted from governments consensus on the delegation of authorities of international community to the UN Security Council(Note11)in order to preserve the cracked security barrier of societies against national sovereignties insurgency through "collective security" approach embodied in the Charter of the United Nations and at the same time, with a blend of the theory of "balance of powers" which is inherent in the permanent members of the Security Council votes.

Economic sanctions according to the origin of its formation and also historical experiences of applying them has always been as a reaction against the governments risky behavior so that before the international community 
resort to force and apply military approach, be able to prevent norm breaking of ruling powers by economic approaches. As has been said: the economic sanction "that first stage is sending a signal from the affected country, showing its displeasure of the new policy of the target."(Khalil, 2004,p.15)Also "another focus of inquiry in the sanctions literature, most prevalent among political scientists, is the role of domestic institutions and politics in determining both the likelihood that sanctions will be used and the political outcome of sanctions. One of the most important aspects of domestic institutions is the nature of the political regime in both target and sanctioner, characterized as either democratic or non-democratic."(Kaempfer \& Lowenberg,2007,p.898)So the aims of sanctions are aggressive, defensive and communicative and from another point of view "as regards objectives of sanctions, following Barber (1979) it is possible to group them into three categories. There are 'primary objectives' concerned with the actions and behavior of governments against whom the sanctions are directed. The 'secondary objectives' are related to status, behavior and expectations of governments imposing sanctions. Finally the 'tertiary objectives' are concerned with the broader international considerations, relating either to the structure of international system as a whole, or to some parts of it. These three categories do not exclude each other but can coexist and overlap in some cases."(Caruso, 2003,p. 4)

A notable point is that despite collision of opinions about whether economic sanctions realize the goals of the UN Security Council and the majority of the international community or not, it should be noted that it may be not possible to measure the impact of sanctions on the governments and the possibility of changing the approach of the transgressive governments due to sanctions is not so clear and measurable, but what is certain and evident is that: sanctions definitely will inflict serious and numerous damages on growth and economic development of a country and, consequently, the lives of the citizens of a state; citizens who ,in most cases, do not have the slightest role in the performance of their government because of the political nature of the offending governments. "Research has shown that substantial costs can be expected during sanction episodes in terms of health (Garfield, Devin \& Fausey, 1995), gender (Drury \& Peksen, 2012) and human rights (Browne, 2011) ... Reductions in economic growth in general are associated with worse performance on human development indicators such as life expectancy, child mortality, primary completion rates and female enrolment rates. Analyzing this general pattern for 163 countries over the period 1980-2008, the World Bank (2010) finds that contractions of economic activity have been associated with deteriorating social indicators."(Dizaji \& Bergeijk, 2013,p. 734)That is why the task of United Nations in imposing sanctions seems sensitive and difficult because while considering individuals' fundamental rights must change target government policies, albeit in some cases applying the approaches that can maintain in such situation is demanding. But it should not be neglected that the factor of civil rights violation is the sanctioned government policies and pressures caused by sanctions seek to break the approaches which has been operating and causing the breach of peace and creating unrest.

After all, sanctions are aimed at changing the conflicting approaches of the state in international scope and applying sanctions, in sum, are considered as a reaction to the non-observance of international law regulations and breach of commitments were approved by representatives of the states and in the end, any kinds of sanctions lead to a lot of covert and overt damages to the growth and economic development of a country. Even if a government has criticism and objection over international interactions or treats established norms challenging is the only alternative to sudden withdrawal of all commitments assumed in the past? Historical experience of imposing sanctions reflects the association between the cycle of breaking the norm, sanctions and lack of economic development on the one hand and on the other hand, the nature of the political system and approaches of the target countries.(Note 12)

\section{Case Study: Iraq}

"Just a decade ago [1980], Iraq boasted one of the most modern infrastructures and highest standards of living in the Middle East. The world's second largest oil producer, it had in recent decades used oil revenues for ambitious projects and development programmes, as well as to build one of the most powerful armed forces in the Arab world. It had established a modern, complex health care system, with giant hospitals built on Western models and using the latest equipment. It had constructed sophisticated water-treatment and pumping facilities. It had an extensive school and university system. By 1990, therefore, Iraq presented some of the features typical of a modern society: reliance on imported food (about $70 \%$ of the calories in Iraq were imported in the 1980s), dependence on imported technology and engineering skills, and interdependence of the different branches of the economy, accompanied by an attitude that "the government will do it for you" and "to replace is better than to repair"."'( International committee of the Red Cross[ICRC],1999) Once Iraqi forces invaded Kuwait on 2 August 1990, the UN Security Council demanded immediate withdrawal of Iraqi forces from Kuwait. The Iraqi government's refusal of this order and their lack of cooperation prompted the UN Security Council to adopt the resolution 1441 on 8 November 2002 in which unanimously declared that Iraq has been and remains in material 
breach of its obligations, in particular through Iraq's failure to cooperate with "International Atomic Energy Agency". While providing the final opportunity to comply with its obligations and issued resolutions stipulated articles, especially in relation to chemical weapons disarmament, stressed that: "the Council has repeatedly warned Iraq that it will face serious consequences as a result of its continued violations of its obligations." (Note 13)

Following the Iraqi government's lack of commitment to the obligations related to international peace and security from the 1990 to 2005, the projects of institutions such as "International Bank for Reconstruction and, Development" and "Institute for International Development" were cut, economic development and growth process raptured and socio-economic welfare of the citizens demoted. "In 1990, using 1987 statistics, the UN Human Development Report classed Iraq as having high medium human development, 54th in the world. In 1998, based on 1995 statistics, the report place Iraq at 127th in the world."(Gottstein, 1998)

It is noteworthy that according to chapter VII of the UN Charter, the process of imposing sanctions has been planned so that the Security Council alters trespassing government policies by the economic levers before being forced to adopt military approach and to avoid war and its immediate and definite consequences as much as possible. The continuation of sanctions and military approach is due to target state's insistence on the continuation of its previous actions. When in expressing the consequences of sanctions it is said that, for instance: "During the sanctions against Iraq diarrheal disease killed Iraqi children..." the significant question is that when a government is not able to control grounds of disease such as diarrhea what purpose does it follow by proliferation of weapons of mass destruction or campaign to the other countries? The experience of the invasion of Kuwait in 1990 and violation the territorial integrity of Iran in 1980 was an evidence on the norm-deviation and irresponsible nature of the Iraqi Ba'ath government in multiple aspects of governance.

\section{Conclusion}

Reviewing the role, position and capabilities of international law in economic development focusing on philosophy and existing essence of frameworks, norms and international organizations on the one hand and on the other hand, the relationship between observance of international norms as the main variable in the development or underdevelopment of a country, has formed the core of the study. As mentioned in the introduction, desirable economic development of this study is considering individuals' welfare and economic security.

On the role of international law in the field of economic development and protecting economic rights of communities and the development of human welfare, this article believes: since the ultimate subject of international law- after states and international organizations - are "people" and the outcomes of all efforts and approaches taken by organizations and governments eventually lead to this group, therefore the substantive aspect of international law (at least on the basis of the achievements of human civilization till now) have the mission to demands basic human needs and have permission to provide needed mechanisms to achieve it. Hence, in the respect of intra-context functions of international law it is worth noting to Art. 55 the UN Charter and Art. 22 the Universal Declaration of Human Rights. Furthermore, effective intellectual support in creating formed international framework and acceptance of the principles and its prospects by the all states of the world and also confirming its positive role in achieving the objectives by different schools of thought, as well as the integration of liberal and critics thinking represented in organizations such as WTO and UNCTAD in the United Nations shows the inherent capabilities of international law in the realization of human needs such as economic development.

Today, the membership of almost all states of the world in the UN and the general consensus on the nature of the formation of these organizations and international consensus to conclude the ratifications such as "Declaration on the Right to Development" and "Millennium Development Goals"(MDGs) and acceptance of principles and goals of organizations such as WTO by states indicate the fact that making peace is the absolute right of human community, and expansion of welfare and basic needs of the nations is one of the component for achieving it. One of the principles of WTO is the "most favoured nation" principle which indicates the multilateralism of this organization and considering the collective common interests. Obviously, enjoying functional benefits of these institutions, positive impressionability as a result of their achievements, creating a propitious environment to realize intended objectives of international ratifications and ultimately, attracting development indicators require mutual building trust and consensus and commitment to the forming principles of aforementioned organizations. There are, partly, suspicions on the part of some of the common beliefs in developing countries and the Third World that the admission of members in the mentioned organizations and creating suitable interaction with them is subject to a desirable governance whose components has been articulated by influential members of these 
organizations and they recognize good gainings only for "good boys". "Thomas Lairson" believes the important and permanent feature of the global economy is inequality (Note 14) and this article believes that law has never been and never will be separate from politics. Therefore, clash of ideas and disagreements widely in today's massive human gathering is consistent with the long process of historical experience. Also, in the economic interaction competitiveness is commonplace and normal even domestically. Therefore, it is important to reduce the disadvantageous consequences resulting from inconsistency and disagreements in international relations and quotas imposition of the states on world economy to attain common interest and more sustainable peace through international interactions. So, it should be considered by national sovereignties and supranational institutions that past experiences and teachings cannot be overlooked and not to put the fate of a society to the various ideological tests. Since the matter of human sciences is, immediately, human and human society, the space of the activities of such scope does not accept to experience repeated trial and error, because if international peace requires full integration of all nations' ideologies(in terms of form and content), such event would not have occurred. So, the correct path is the one which provide the greatest benefit to human in order for his growth and excellence in the shortest time with the least damages to his material and spiritual life and the world around him. In other words, the correct path is the less costly one which among the most effective mechanisms to achieve this aim is respect for differences and commitment to the international agreements. Otherwise, insisting on differences and adopting anger and suspicion approaches on the part of any of the political, ideological etc. groups lead to nothing but the continuation of unrest, lack of stability and underdevelopment of the society.

According to this study, most factors of underdevelopment are derived from the political structure governing the developing countries, especially those "Dualist States" that still have incredulous view on international law and see their seemingly national! authoritarian reputation in conflict and confrontation with the organizations and rules of international law and in a word, their view on international law is underdeveloped. The rule of law and respect for international commitments are essential components in the development process and assistance in achieving the ultimate goal of international law. Published statistics and reports implying that the top 10 countries in "the Global Democracy Ranking" in 2013 in terms of human development index are also among the countries which enjoy "very high human development". Also, countries which had a high rate of "GDP" in 2013 were among very peaceful countries in terms of "Peace Index" and were among corruption-free countries in terms of "Corruption Perception Index". (Note 15) On the other side, there are nations who have always been grappling with an unpleasant cycle of undesirable governance, unrest, administrative corruption, poverty and lack of development. Lack of social security, political instability, lack of rule of law, administrative corruption and the activities of armed militias are the characteristics and realities of the countries in which the economy and the lives of their citizens have been intertwined with poverty and underdevelopment.

Trying to understand that the lack of economic development is the main reason for lack of other aspects of development such as social, cultural etc. development or vice versa is a vicious circle, because as was mentioned earlier the dimensions of development should be known in relation to each other. Thus, it is evident that observance of the international commitments makes a government enjoy a legal entity in the international interactions, devoid of accusations arising from international criminal act or omission and yet taking part in numerous fields such as economics and international trade shall be increased. If national sovereignties are assumed as a real entity, the aspiration of achieving independence cannot be the evolution point of any creature. As the process of human grow this considered in three stages of: dependence, independence and interdependence, among the properties of developed government are to establish a stable and favorable interaction with other states and to create interdependence. In all ages for their survival, human societies have required numerous dealings with each other. Domestic production needs export and attracting foreign investment requires a suitable substrates. In addition, international economic cooperation shall be made in the form of dynamic interaction and based on inclusive trust.

As proposed, economic interactions and ties will link the fate of nations (Note 16) and subsequently, not only it eliminate the consequences of poverty and deprivation, but also such links would be an effective step to consolidate the foundations of peace and international stability. In other words, the creation of international interdependence can be seen as international peace-making tools. This article confirms that the present study does not refers to all the components and characteristics needed to achieve economic development and some other questions may be raised in the context of concerned issues. However, proof of this hypothesis is based on this relationship that: development components, in its general sense, are correlated and economic development entails desirable politic infrastructures, and the development-oriented policy requires normative tendencies and reconstructing desired role for promoting international norms by the states in the limit of rule of international law and observing its regulations. 


\section{Acknowledgments}

I would like to thank Professor José Enrique Alvarez for critiquing the manuscript, Mr. Hamed Omidi for helpful cooperation, my university professors: Dr. Mehdi Abbasi Sarmadi, Dr. Mahin Sobhani, Dr. Zohreh Rahmani and also thank my dear Khatoon

\section{References}

Akehurst, M. (1987). A Modern Introduction to International Law (6th ed.). The Academic division of unwin Hyman Ltd, London.

Blomstron, M., \& Kokko, A. (2003). Human Capital And Inward FDI, Word doc: CEPR-WP, Working Paper 167.

Busse, M., \& Groizard, J. L. (2006). Foreign Direct Investment, Regulations, and Growth", WPS 3882World Bank Policy Research Working Paper.

Capps, P. (2001). The Kantian Project in Modern International Legal Theory. EJIL., 12(5), 1003-1025. http://dx.doi.org/10.1093/ejil/12.5.1003

Caruso, R. (2003). The Impact of International Economic Sanctions on Trade, An empirical Analysis, Paper prepared for the European Peace Science Conference, Amsterdam. Retrieved from http://papers.ssrn.com/sol3/papers.cfm?abstract_id=895841

Collins, S. (2009). The Efficacy of Economic Sanctions and American Foreign Policy in the Unipolar era. The new England Journal of political Science, III(2), 235-263.

Dizaji, S. F., \& Bergeijk, P. A. G. V. (2013). Potential early Phase Success and Ultimate Failure of Economic Sanctions: A VAR approach with an application to Iran. Journal of Peace Research, 50(6). 721-736. http://dx.doi.org/10.1177/0022343313485487

Dolzer, R., \& Schreuer, C. (2008). Principles of International Investment Law (1st ed.). Oxford University Press. http://dx.doi.org/10.1093/law:iic/9780199211753.001.1

Food and Agriculture Organization of the United Nations. (2012). Globally almost 870 million chronically undernourished - new hunger report. Retrieved March 14, 2016, from http://www.fao.org/news/story/en/item/161819/icode

Gordon, K. (2008). Investment Guarantees and Political Risk Insurance: Institutions, Incentives, and Development, OECD Investment Policy Perspectives. 91-122.

Gottstein, U. (1998). The Effects of Sanctions on the Civilian Community of Iraq, Medical Association for Prevention of War. Retrieved from http://www.mapw.org.au

Guardian. (2011, May 12). Forty-eight women raped every hour in Congo, study finds. Retrieved March 13, 2016 from http://www.theguardian.com/ world/2011/may/12/48-women-raped-hour-congo

Herz, S., Genovese, K., Herbertson, K., \& Perrault, A. (2008). The International Finance Corporation's performance standards and The Equator, principales: Respecting Human Rights and violatiolls?" A Submission to the U.N. Special Representative to the Secretary General on Human Rights and Transnational Corporations and other Business Enterprises. Center for International Environmental Law, Bank Information Center, Bank Track, Oxfam Australia, World Resources Institute 2.

Howse, R. (2000). Democracy, Science, and Free Trade: Risk Regulation on Trial at The World Trade Organization, 98 Mich. L. Rev. http://dx.doi.org/10.2307/1290307

Hunya, G. (2012). The Role of Multinational Companies in International Business Integration, the Vienna Institute for International Economic Studies WiiW, 384 Research Reports.

Institute Economics \& Peace. (2014). Global Peace Index, Measuring Peace and Assessing Country. Retrieved from http://www.economicsandpeace.org

International Bank for Reconstruction and Development \& World Bank. (1998). Development and Human Rights, The Role of the World Bank, Library of Congress Cataloging-in-Publication Data ,USA.

International committee of the Red Cross. (1999). Iraq: 1989-1999, a decade of sanctions, Resource Centre. Retrieved from http: //www.icrc.org/eng/resources/documents/ misc/57jqap.htm

Jakobsen, J. (2011). Political Risk for Multinational Companies: Empirical evidence from a new dataset. Retrieved from http://www.wiscnetwork.org/porto2011/papers/WISC_2011-560.pdf 
Kaempfer, W. H., \& Lowenberg, A. D. (2007). The Political Economy of Economic Sanctions. Handbook of Defense Economics, 2, 868-911. Retrieved from http://www.sfu.ca

Kelsen, H. (2002). Introduction to the problems of legal theory (1st ed.). (translationof the first edition of the pure theory of law, Paulson. B. L \& Paulson. S. L Trans.).

Khalil, M. A. (2004). Toward more Humane and Effective Economic Sanctions: with special reference to Iraq. Southwestern Economic Proceedings, 13-26. $\quad$ Retrieved from http://swer.wtamu.edu/sites/default/files/Data/13\%20-\%2026-213-788-1-PB.pdf

Kingsbury, B., \& Casini, L. (2009). Global Administrative Law Dimensions of International Organizations Law. $\begin{array}{lllll}\text { International } \quad \text { Organizations } & \text { Review, } & \text { 319-358. }\end{array}$ http://dx.doi.org/10.1163/157237409X12670188734311

Miller, R. C. (2008). International Political Economy, Contrasting World Views, published by Routledge, Taylor \& Francis e-Library. http://dx.doi.org/10.4324/9780203927236

Nourbakhshian, M. R., Hosseini, S., Aghapour, A. H., \& Gheshmi, R. (2012). The Contribution of Foreign Direct Investment into Home Country's Development. International Journal of Business and Social Science, 3(2), 275-287.

Oden, B. (2010). Review Essay, The UN and Development: From Aid to Cooperation. Forum for Development Studies, 37(2), 269-279. Routledge: Taylor \& Francis Group. Retrieved from http://www.unhistory.org/reviews/Oden_Stokke.pdf

Park, W., \& Yanos, A. (2006). Treaty Obligations and National Law: Emerging Conflicts in International Arbitration. Hastings Law Journal, 58, 251.

Piranio, C. (2015). The Philosophy of International Law. Sciences Po Paris, Le Havre.

Rousseau, J. J. (2002). The Social Contract(G.D.H. Cole, Trans). public domain.

Sangroula, Y. (2010). International Treaties: Features and Importance from International Law Perspective. Retrieved from http://ssrn.com

Show, N. S. (2003). International law (5th ed.). The press syndicate of the university of Cambridge. http://dx.doi.org/10.1017/CBO9781139051903

Shukla, S. P. (2000). From GATT to WTO and Beyond, Working Papers, UNU World Institute for Development Economics Research(UNU/WIDER) NO.195.

Sottilotta, C. M. (2013). Political Risk: Concepts, Definitions, Challenges, Luiss School of Government, Working Paper Series 6.

The World Factbook. $\quad$ (2014). Retrieved from https://www.cia.gov/library/publications/resources/the-world-factbook

Transparency International Organization. (2013). Corruption Perceptions Index. Retrieved from http:/www.transparency.org/cpi

Trubek, D. M. (2003). The Rule of Law in Development Assistance: Past, Present, and Future. Retrieved from http://www.dev.law.wisc.edu//facstaff/trubek/RuleofLaw.htm

United Nations Development Programme. (2013). International Human Development Indicators. Retrieved from http://hdr.undp.org/en/countries/profiles/

United Nations World Food Programme. (2012). Hunger Statistics, No 9. Retrieved March 14, 2016, from https://www.wfp.org/hunger/stats

World Bank. (2010). Retrieved from http://www.worldbank.org/en/country/

\section{Notes}

Note 1. For example: art. 1, Sec $3 \&$ art.55, para a of the U.N. Charter, art.25 of the Universal Declaration of Human Rights, art.11 of the International Covenant on Economic, Social and cultural Rights.

Note 2. "to establish conditions under which justice and respect for the obligations arising from treaties and other sources of international law can be maintained to employ international machinery for the promotion of the economic and social advancement of all peoples" 
Note 3. Declaration on the Right to Development, December 4. 1986.G.A. Res.41/128.U.N. Doc. A/RES/41/128.

Note 4. See: Pease, K.K.S. 2009. "International Organizations: Perspectives on Governance in the Twenty-first Century", Prentice Hall, the section: development.

Note 5. G.A. Res. 1995 (XIX), U.N. Doc.A/RES $1995 \quad$ (Dec.30, 1964) see http://www.un.org/documents/ga/res/19/ares19.htm

Note 6. G.A. Res. 2093(XX),U.N.Doc. A/RES2093 (Dec.20,1965) see http://www.un.org/en/ga/search/view_doc.asp?symbol=A/RES/2093(XX)

Note 7. G.A. Res. 2152(XXI),U.N. Doc. A/RES2152 (November. 17, 1966) see https://documents-dds-ny.un.org/doc/RESOLUTION/GEN/NR0/ 004 / 55/IMG/NR000455.pdf?OpenElement

Note 8. The Vienna Convention on the Law of Treaties, May.23,1969.Entried into force:January.27, 1980.

Note 9. See "5 The WTO can ... encourage good governance", available at $<$ https://www.wto.org/ english/ thewto_e/whatis_e/10thi_e/10thi05_e.htm >

Note 10. See "The World Bank, What We Do", available at http://www.worldbank.org/en/about/what-we-do

Note 11. See: Lowenfeld, A. F. 2008. "International Economic Law", Oxford University Press Inc, New York. Part VIII: Economic Controls for Political Ends.

Note 12. See: Biersteker, $\mathrm{T}$ \& Hudakova, Z, UN sanctions and peace negotiations: possibilities for complementarity, The Oslo forum papers, Centre for Humanitarian Dialogue, Geneva, N 004 , January 2015.

Note 13. See: S.C. Res. 1441, U.N. Doc. S/RES/1441 (8 November 2002) section:13. available at http://www.un.org/Depts/unmovic/documents/1441.pdf

Note 14. See: Lairson, T.D \& Skidmore, D . 2002." International Political Economy: The Struggle for Power and Wealth", Wadsworth Publishing Company.

Note 15. See: Human Development Index, Peace Index, Corruption Perception Index \& Global Democracy Ranking in 2013.

Note 16. The theories of "Interdependence" and "Integration" (customs union, optimal currency area) are used to confirm this view.

\section{Copyrights}

Copyright for this article is retained by the author(s), with first publication rights granted to the journal.

This is an open-access article distributed under the terms and conditions of the Creative Commons Attribution license (http://creativecommons.org/licenses/by/4.0/). 